\title{
Gaya Kepemimpinan Situasional, Budaya Organisasi, Tingkat Pendidikan, Motivasi dan Kinerja Karyawan
}

\author{
I Gusti Agung Oka Sudeva1 \\ Fakultas Ekonomi dan Bisnis \\ Universitas Udayana, Indonesia
}

\author{
Ni Ketut Rasmini2 \\ Fakultas Ekonomi dan Bisnis \\ Universitas Udayana, Indonesia
}

\begin{abstract}
Surel: okasudeva@gmail.com
ABSTRAK

Pada tahun 2019-2020, 21,4 persen koperasi dibubarkan. Meningkatnya pembubaran koperasi ini diduga karena pengelolaan koperasi dan kinerja karyawan yang kurang baik. Penelitian ini bertujuan untuk mengetahui pengaruh gaya kepemimpinan situasional, budaya organisasi, tingkat pendidikan, dan motivasi terhadap kinerja karyawan Koperasi Kabupaten Klungkung dengan pendekatan kuantitatif. Pengumpulan data dilakukan melalui kuesioner. Populasi adalah seluruh koperasi yang berlokasi di Kabupaten Klungkung dengan koperasi yang ada di Kecamatan Klungkung sebagai sampel melalui purposive sampling. Teknik analisis yang digunakan adalah regresi linear berganda. Berdasarkan pengujian hipotesis ditemukan bahwa gaya kepemimpinan situasional, budaya organisasi, tingkat pendidikan dan motivasi berpengaruh positif terhadap kinerja karyawan. Hasil ini mendukung teori atribusi dan teori keperilakuan organisasi.
\end{abstract}

Kata Kunci: Kepemimpinan Situasional; Budaya organisasi; Tingkat Pendidikan; Motivasi; Kinerja Karyawan.

\section{Situational Leadership Style, Organizational Culture, Education Level, Employee Motivation and Performance}

\begin{abstract}
In 2019-2020, 21.4 percent of the cooperatives were dissolved. The increased dissolution of cooperatives is thought to be due to poor cooperativemanagement and employee performance. This study aims to determine the effect of situational leadership style, organizational culture, educational level, and motivation on employee performance of Klungkung Regency Cooperative with a quantitative approach. Data collection was carried out through a questionnaire. The population is all cooperatives located in Klungkung with cooperatives in Klungkung as samples through purposive sampling. The analysis technique used is multiple linear regression. Results show that situational leadership, organizational culture, education level and motivation have a positive effecton employee performance. These results support attribution theory and organizational behavior theory.
\end{abstract}

Keywords: Situational Leadership; Organizational Culture; Education Level; Motivation; Employee Performance.

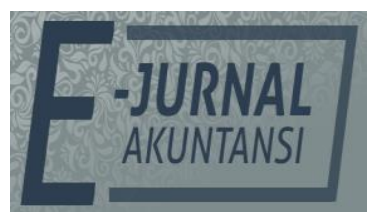

e-ISSN 2302-8556

Vol. 31 No. 11

Denpasar, November 2021 Hal. 2827-2841

DOI:

10.24843/EJA.2021.v31.i11.p12

PENGUTIPAN: Sudeva, I. G. A. O., \& Rasmini, N. K. (2021). Gaya Kepemimpinan Situasional, Budaya Organisasi, Tingkat

Pendidikan, Motivasi dan Kinerja Karyawan. E-Jurnal Akuntansi, 31(11), 2827-2841

RIWAYAT ARTIKEL: Artikel Masuk: 8 April 2021 Artikel Diterima: 4 November 2021

Artikel dapat diakses: https:/ / ojs.unud.ac.id/index.php/Akuntansi/index 


\section{PENDAHULUAN}

Saat ini perekonomian di Indonesia mengalami tekanan akibat adanya Virus Corona. Virus ini merupakan Coronavirus jenis baru yang ditemukan di Wuhan, Hubei, China pada tahun 2019 (Wang et al., 2020). Oleh karena itu, Coronavirus jenis baru ini diberi nama Coronavirus disease-2019 yang disingkat menjadi COVID19. Pada manusia, Coronavirus menyebabkan penyakit infeksi saluran pernafasan, seperti flu, MERS (Middle East Respiratory Syndrome), dan SARS (Severe Acute Respiratory Syndrome). Sejak ditemukan COVID-19 menyebar secara luas hingga mengakibatkan pandemi global yang berlangsung sampai saat ini, tercatat 199 negara yang masyarakatnya telah terinfeksi COVID-19 termasuk Indonesia. Pandemi COVID-19 ini menjadi tantangan besar bagi seluruh koperasi yang ada di Indonesia dalam menjalanakan usahanya. Koperasi yang terdampak pandemi COVID-19 ialah koperasi yang bergerak pada bidang jasa dan produksi, dimana koperasi tersebut mengalami penurunan penjualan, penurunan pendapatan bunga dan berujung pada menurunnya profitabilitas

Pada tahun 2019 Kecamatan Klungkung memiliki persentase jumlah koperasi tidak aktif sebesar 7,7 persen sedangkan pada tahun 2020 koperasi yg tidak aktif mengalami peningkatan menjadi 21,4 persen. Koperasi dikatakan tidak aktif jika koperasi tersebut tidak melakukan Rapat Anggota Tahunan(RAT)dalam tiga tahun berturut-turut dan tidak melakukan kegiatan usahanya. Koperasi yang tidak aktif ini selain karena tidak melaksanakan RAT bisa juga disebabkan karena banyaknya kredit macet dan kurangnya kesadaran anggota dalam berkoperasi. Sejak bulan April 2020 hampir semua koperasi di Klungkung mengalami penurunan laba, khususnya Koperasi Simpan-Pinjam (KSP). Hal ini terjadi akibat dampak dari pandemi COVID-19 yang mulai menyebar di Bali pada pertengahan bulan Maret 2020. Banyak anggota yang hanya bisa membayar bunga kredit, disisi lain anggota yang memiliki deposito menarik simpanannya. Disinilah peran pemimpin dan kinerja karyawan yang harus melakukan pendekatan ke anggota dan meningkatkan kinerja karyawannya, agar koperasi tetap bisa bertahan.

Koperasi merupakan sebuah organisasi yang memiliki berbagai sumber daya fisik, finansial, ilmu pengetahuan dan teknologi, serta manusia. Salah satu sumber daya yang terpenting dalam organisasi yaitu, manusia. Pada umumnya sebuah organisasi mengharapkan mempunyai sumber daya manusia yang berkualitas sehingga mampu mewujudkan tujuan yang diharapkan organisasi (Rudiantoro, 2017). Kinerja karyawan didefinisikan sebagai gambaran hasil pencapaian dari pelaksanaan kegiatan untuk mewujudkan target yang telah ditetapkan oleh perusahaan melalui sebuah perencanaan strategi organisasi (Karma et al., 2017). Peningkatan kinerja karyawan tidak akan terlepas dari sosok pemimpin sebagai pihak yang bertanggung jawab dalam organisasi. Apabila pemimpin mampu menjalankan kepemimpinan yang tepat maka tujuan organisasi untuk meningkatkan kinerja karyawan akan lebih mudah tercapai. Seorang pemimpin yang mampu mengayomi bawahan dengan baik, cenderung akan memotivasi karyawan untuk meningkatkan kualitas kerja yang dimiliki (Dermawan et al., 2018). Kepemimpinan akan efektif apabila kemampuan diri dari pemimpin mendukung dalam menghadapi situasi serta kondisi yang berasal dari lingkungan internal maupun eksternal perusahaan (Fajrin \& Susilo, 2018). 
Gaya kepemimpinan didefinisikan sebagai gambaran bagaimana seorang pemimpin mampu mempengaruhi karyawan dan membuat karyawan bertindak sesuai dengan arahan yang pemimpin berikan tanpa ada paksaan dan rasa takut dalam diri karyawan. Pemimpin yang sukses adalah pemimpin yang dapat menyesuaikan gaya kepemimpinan dengan kebutuhan situasi. Dalam hal ini, maka gaya kepemimpinan yang digunakan adalah kepemimpinan situsional, dimana pimpinan akan memberikan kontribusi paling baik untuk pencapaian sasaran organisasi yang memiliki situasi dan lingkungan berbeda atau bervariasi. Paul Hersey dan Ken Blanchard mencetuskan sebuah model kepemimpinan yang disebut dengan Teori Kepemimpinan Situasional. Gaya kepemimpinan situasional sangatlah fleksibel, sehingga sangat cocok untuk mewakili kondisi persaingan global yang terus saja mengalami perubahan dengan sangat pesat. Dengan demikian, gaya kepemimpinan seseorang sangat diperlukan dalam menghadapi situasi serta kondisi tersebut (Azizah et al., 2017).

Faktor lainnya yang dapat memengaruhi kinerja adalah "budaya organisasi (Hamid \& Ruhana, 2017). Budaya organisasi yang kuat memiliki potensi meningkatkan kinerja, dan sebaliknya bila budaya organisasinya lemah maka mengakibatkan kinerja menurun (Sahyoni \& Supartha, 2020). Oleh karena besarnya peran budaya organisasi, sudah selayaknya bagi perusahaan dalam melakukan proses transformasi juga memperhatikan aspek budaya organisasi (Wiradana \& Dewi, 2021). Lebih lanjut faktor-faktor yang juga perlu diperhatikan untuk meningkatkan kinerja individu seseorang adalah tingkat pendidikan (Anjani dan Wirawati, 2018). Pendidikan merupakan unsur yang penting dalam mendukung kinerja individu. Pendidikan pada umumnya berkaitan dengan mempersiapkan calon tenaga yang diperlukan oleh suatu instansi atau organisasi yang lebih menitik beratkan pada pengembangan kemampuan umum (Belawa dan Pande Dwiana Putra, 2018). Selain faktor gaya kepemimpinan, budaya organisasi dan tingkat pendidikan, untuk membentuk karyawan yang berkualitas sehingga terciptanya peningkatan kinerja perusahaan secara keseluruhan, juga ditunjang oleh faktor motivasi. Motivasi yaitu gagasan dan inisiatif untuk mendorong individu melakukan sesuatu atau untuk kinerja pekerjaan yang lebih baik (Noviani \& Widhiyani, 2018)."

Penelitian ini menggunakan "teori atribusi sebagai grand theory dan teori keperilakuan organisasi sebagai supporting theory. Teori Atribusi (Atribution Theory) merupakan teori yang menjelaskan tentang perilaku seseorang (Sawitri et al., 2020). Teori atribusi mempelajari proses bagaimana seseorang menginterpretasikan suatu peristiwa, alasan, atau sebab perilakunya (Kodyawati dan Dewi, 2019). Teori ini menjelaskan situasi di sekitar yang menyebabkan perilaku seseorang dalam persepsi sosial disebut dengan dispositional attributions dan situational atributions (Putra \& Setiawan, 2020). Dispositional atributions merupakan penyebab internal yang mengacu pada aspek perilaku individual yang ada dalam diri seseorang, misalnya kepribadian, persepsi diri, kemampuan, dan motivasi. Sedangkan situational attributions merupakan penyebab eksternal yang mengacu pada lingkungan sekitar yang dapat memengaruhi perilaku, misalnya kondisi sosial, nilai-nilai sosial, dan pandangan masyarakat. Teori atribusi telah menjadi salah satu pendekatan yang paling relevan dalam menjelaskan perilaku akademik 


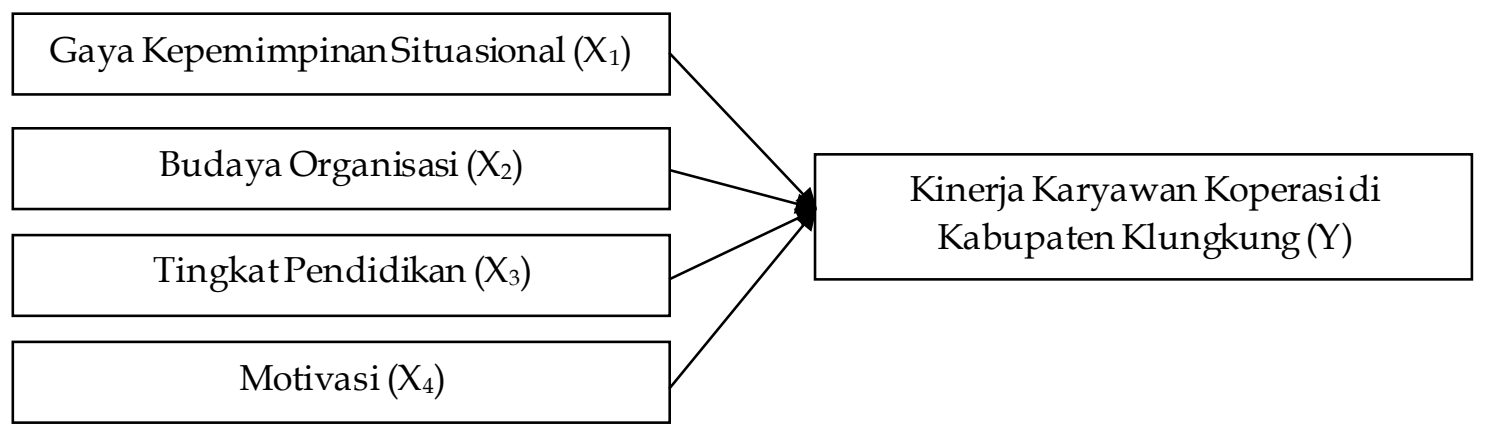

Gambar 1. Kerangka Konseptual

Teori atribusi adalah teori yang mempelajari proses bagaimana seseorang menginterpretasikan suatu peristiwa, alasan, atau sebab perilakunya. Teori ini menjelaskan situasi di sekitar yang menyebabkan perilaku seseorang dalam persepsi sosial yang disebut dengan dispositional attributions dan situasional attributions. Gaya kepemimpinan situasional berhubungan dengan situasional attributions yang artinya penyebab eksternal yang mengacu pada lingkungan sekitar yang dapat memengaruhi perilaku seseorang. Gaya kepemimpinan situasional merupakan gaya kepemimpinan yang dilakukan berdasarkan situasi dan lingkungan yang berbeda atau bervariasi. Rahadiyan et al. (2019), Samsuri et al.(2020), Setyorini et al. (2018) secara empiris membuktikan adanya pengaruh positif gaya kepemimpinan situasional terhadap kinerja karyawan.

$\mathrm{H}_{1}$ : Gaya kepemimpinan situasional berpengaruh positif terhadap kinerja karyawan koperasi di Kabupaten Klungkung

Teori keperilakuan organisasi adalah studi yang menyangkut aspek-aspek tingkah laku manusia dalam organisasi atau kelompok tertentu. Teori keperilakuan organisasi yang menyangkut aspek pengaruh organisasi terhadap manusia berhubungan dalam budaya organisasi karena, seorang anggota organisasi akan cenderung mempersepsikan budaya organisasi berdasarkan apa yang mereka lihat atau dengar di dalam organisasi. Budaya organisasi merupakan suatu elemen yang spesifik yang dapat memberikan pengaruh pada kinerja karyawan (Perawati \& Badera, 2018). Isa et al. (2016) dan Wardani et al. (2016) yang menganalisis Pengaruh budaya organisasi pada kinerja secara empiris membuktikan bahwa budaya organisasi memilik pengaruh positif pada kinerja karyawan. Semakin tinggi pemahaman karyawan tentang budaya organisasi semakin tinggi pula kinerja karyawan.

$\mathrm{H}_{2}$ : Budaya organisasi berpengaruh positif terhadap kinerja karyawan koperasi di Kabupaten Klungkung.

Untuk meningkatkan kemampuan bekerja seorang karyawan diperlukan adanya pendidikan, karena semakin tinggi tingkat pendidikan karyawan maka secara tidak langsung akan memberikan kontribusi yang lebih bagi organisasi untuk lebih berkembang di masa yang akan datang. Salwa et al. (2019) dalam penelitiannya menyatakan bahwa Pendidikan yang dimiliki karyawan memberikan pengaruh positif terhadap kinerja karyawan. Hal yang sama dibuktikan oleh Abdulrahamon et al. (2018), bahwa tingkat pendidikan yang dimiliki oleh karyawan berpengaruh positif terhadap kinerja karyawan.

$\mathrm{H}_{3}$ : Tingkat pendidikan berpengaruh positif terhadap kinerja karyawan koperasi di Kabupaten Klungkung. 
Aspek pengaruh manusia terhadap organisasi berhubungan dengan motivasi, karena semakin tinggi motivasi yang diberikan kepada karyawan tentunya akan membuat organisasi lebih mudah dalam mencapai tujuannya (Noviani dan Widhiyani, 2018). Hikmah dan Sherlie (2020) yang mengalisis pengaruh motivasi terhadap kinerja secara empiris membuktikan bahwa motivasi berpengaruh positif pada kinerja karyawan. Kuranchie-Mensah \& AmponsahTawiah (2016) menjelaskan bahwa ketika karyawan tidak memiliki motivasi, karyawan tidak akan bekerja dengan baik dan tujuan perusahaan akan sulit tercapai. Robescu \& Iancu (2016), A prila \& Artha Wibawa (2020) memperoleh hasil analisis yang menyatakan bahwa motivasi berpengaruh positif pada kinerja karyawan. Semakin tinggi motivasi semakin tinggi pula kinerja karyawan.

$\mathrm{H}_{4}$ : Motivasi berpengaruh positif terhadap kinerja karyawan koperasi di Kabupaten Klungkung.

\section{METODE PENELITIAN}

Penelitian ini menggunakan pendekatan kuantitatif yang berbentuk asosiatif. Penelitian ini dilakukan di koperasi Kabupaten Klungkung dengan mengambil sampel koperasi di Kecamatan Klungkung. Adapun alasan peneliti melakukan penelitian koperasi di Kecamatan Klungkung karena memiliki jumlah koperasi sebanyak 78 koperasi, dimana jumlah tersebut merupakan yang paling banyak dari Kecamatan lainnya, selain itu jumlah koperasi yang tidak aktif di Kecamatan Klungkung memiliki jumlah terbanyak dan mengalami peningkatan setiap tahunnya. Populasi penelitian ini adalah seluruh koperasi yang berlokasi di Kabupaten Klungkung. Pada penelitian ini sampel yang di pilih adalah koperasi yang ada di Kecamatan Klungkung. Pertimbangan yang dipakai memilih koperasi di Kecamatan Klungkung karena Kecamatan ini memiliki jumlah koperasi tidak aktif yang meningkat setiap tahunnya.

Penentuan sampel dalam penelitian ini menggunakan metode purposive sampling. Adapun pertimbangan penentuan sampel dalam penelitian ini, Koperasi aktif yang sudah berdiri minimal 5 tahun, karena dengan jangka waktu tersebut, pengelola, pengurus, dan karyawan koperasi tentunya sudah memiliki pengalaman dalam berkoperasi serta Koperasi yang mendapat penilaian sehat dari dinas koperasi. Metode pengumpulan data yang digunakan dalam penelitian ini adalah metode survey.

\section{HASIL DAN PEMBAHASAN}

Responden yang ada di Koperasi Kabupaten Klungkung memiliki karakteristik ataupun identitas yang berbeda dalam melakukan pengisian kuesioner. Responden yang digunakan dalam penelitian ini ditentukan berdasarkan karakteristiknya. Berdasarkan jenis kelamin, jumlah responden yang memiliki jenis kelamin perempuan adalah sebanyak 56 responden dengan persentase 41,48 persen dan responden yang memiliki jenis kelamin laki-laki adalah sebanyak 79 responden dengan persentase sebesar 58,52 persen. Berdasarkan pendidikan, jumlah responden yang pendidikan nya SMA/SMK adalah sebanyak 65 responden dengan persentase 48,15 persen, D1 sebanyak 15 responden dengan persentase 11,11 persen, D3 danS1 masing-masing sebanyak 23 responden dengan 
persentase 17,04 serta responden dengan pendidikan S2 adalah sebanyak 9 responden dengan persentase 6,67 persen.

Tabel 1. Rekapitulasi Hasil Uji Validitas

\begin{tabular}{cccc}
\hline Variabel & Indikator & Korelasi & Sig. \\
\hline Gaya Kepemimpinan & $\mathrm{X}_{1.1}$ & 0,822 & 0,000 \\
Situasional $\left(\mathrm{X}_{1}\right)$ & $\mathrm{X}_{1.2}$ & 0,919 & 0,000 \\
& $\mathrm{X}_{1.3}$ & 0,859 & 0,000 \\
& $\mathrm{X}_{1.4}$ & 0,832 & 0,000 \\
& $\mathrm{X}_{1.5}$ & 0,733 & 0,000 \\
Budaya Organisasi $\left(\mathrm{X}_{2}\right)$ & $\mathrm{X}_{2.1}$ & 0,640 & 0,000 \\
& $\mathrm{X}_{2.2}$ & 0,785 & 0,000 \\
& $\mathrm{X}_{2.3}$ & 0,798 & 0,000 \\
& $\mathrm{X}_{2.4}$ & 0,766 & 0,000 \\
TingkatPendidikan $\left(\mathrm{X}_{3}\right)$ & $\mathrm{X}_{2.5}$ & 0,742 & 0,000 \\
& $\mathrm{X}_{3.1}$ & 0,845 & 0,000 \\
& $\mathrm{X}_{3.2}$ & 0,847 & 0,000 \\
& $\mathrm{X}_{3.3}$ & 0,810 & 0,000 \\
& $\mathrm{X}_{3.4}$ & 0,854 & 0,000 \\
& $\mathrm{X}_{3.5}$ & 0,816 & 0,000 \\
Motivasi $\left(\mathrm{X}_{4}\right)$ & $\mathrm{X}_{4.1}$ & 0,831 & 0,000 \\
& $\mathrm{X}_{4.2}$ & 0,756 & 0,000 \\
& $\mathrm{X}_{4.3}$ & 0,712 & 0,000 \\
& $\mathrm{X}_{4.4}$ & 0,929 & 0,000 \\
& $\mathrm{X}_{4.5}$ & 0,538 & 0,000 \\
& $\mathrm{Y}_{1}$ & 0,770 & 0,000 \\
& $\mathrm{Y}_{2}$ & 0,578 & 0,000 \\
& $\mathrm{Y}_{3}$ & 0,739 & 0,000 \\
& $\mathrm{Y}_{4}$ & 0,916 & 0,000 \\
& $\mathrm{Y}_{5}$ & 0,926 & 0,000 \\
\hline & & & \\
\hline
\end{tabular}

Sumber: Data Penelitian, 2020

Hasil Uji Validitas yang disajikan dalam Tabel 1 menunjukkan bahwa indikator penelitian yang digunakan untuk mengukur variabel gaya kepemimpinan situasional, budaya organisasi, tingkat pendidikan, motivasi, dan kinerja karyawan memiliki nilai koefisien korelasi dengan skor total seluruh butir pernyataan lebih besar dari 0,30 dengan nilai signifikansi lebih kecil dari 0,05). Hal ini menunjukkan bahwa butir-butir pernyataan dalam instrumen penelitian tersebut valid dan layak digunakan sebagai instrumen penelitian.

Tabel 2. Rekapitulasi Hasil Uji Reliabilitas

\begin{tabular}{clc}
\hline No. & \multicolumn{1}{c}{ Variabel } & Cronbach's Alpha \\
\hline 1 & Gaya KepemimpinanSituasional $\left(\mathrm{X}_{1}\right)$ & 0,890 \\
2 & Budaya Organisasi $\left(\mathrm{X}_{2}\right)$ & 0,832 \\
3 & Tingkat Pendidikan $\left(\mathrm{X}_{3}\right)$ & 0,888 \\
4 & Motivasi $\left(\mathrm{X}_{4}\right)$ & 0,804 \\
5 & Kinerja Karyawan & 0,854 \\
\hline
\end{tabular}

Sumber: Data Penelitian, 2020

Hasil Uji Reliabilitas pada Tabel 2 menunjukkan, variabel yang digunakan dalam penelitian ini memiliki koefisien Cronbach's Alpha lebih besar dari 0,60. Jadi dapat dinyatakan bahwa seluruh variabel telah memenuhi syarat reliabilitas atau kehandalan sehingga dapat digunakan untuk dianalisis lebih lanjut. 
Tabel 3. Hasil Uji Statistik Deskriptif

\begin{tabular}{lccccc}
\hline \multicolumn{1}{c}{ Variabel } & $\mathrm{N}$ & Min. & Max. & Mean & Std. Deviation \\
\hline Gaya KepemimpinanSituasional & 135 & 12 & 20 & 16,60 & 2,595 \\
Budaya Organisasi & 135 & 11 & 20 & 16,87 & 2,195 \\
Tingkat Pendidikan & 135 & 11 & 20 & 16,38 & 2,637 \\
Motivasi & 135 & 8 & 20 & 14,89 & 2,888 \\
Kinerja & 135 & 7 & 20 & 13,04 & 3,528 \\
\hline
\end{tabular}

Sumber: Data Penelitian, 2020

Variabel gaya kepemimpinan situasional memiliki nilai minimum sebesar 12 dan nilai maksimum sebesar 20. Variabel gaya kepemimpinan situasional diukur dengan 5 item pernyataan dengan bantuan skala likert 4 poin memiliki ratarata sebesar 16,60. Nilai rata-rata tersebut apabila dibagi dengan 5 item pernyataan diperoleh hasil sebesar 3,32. Nilai rata-rata variabel gaya kepemimpinan situasional sebesar 3,32 berada pada rentang 3,26 - 4,00 yang termasuk ke dalam kriteria sangat tinggi. Hal tersebut berarti bahwa gaya kepemimpinan situasional yang diterapkan di Koperasi Kabupaten Klungkung sangat baik. Nilai standar deviasi gaya kepemimpinan situasional yaitu sebesar 2,595 yang nilainya lebih rendah dibandingkan dengan nilai rata-rata artinya sebaran data terkait dengan gaya kepemimpinan situasional sudah merata.

Variabel budaya organisasi memiliki nilai minimum sebesar 11 dan nilai maksimum sebesar 20. Variabel budaya organisasi diukur dengan 5 item pernyataan dengan bantuan skala likert 4 poin memiliki rata-rata sebesar 16,87. Nilai rata-rata tersebut apabila dibagi dengan 5 item pernyataan diperoleh hasil sebesar 3,37. Nilai rata-rata variabel budaya organisasi sebesar 3,37 berada pada rentang 3,26 - 4,00 yang termasuk ke dalam kriteria sangat tinggi. Hal tersebut berarti bahwa budaya organisasi yang ada di Koperasi Kabupaten Klungkung sangat baik. Nilai standar deviasi budaya organisasi yaitu sebesar 2,195 yang nilainya lebih rendah dibandingkan dengan nilai rata-rata artinya sebaran data terkait dengan budaya organisasi sudah merata.

Variabel tingkat pendidikan memiliki nilai minimum sebesar 11 dan nilai maksimum sebesar 20. Variabel tingkat pendidikan diukur dengan 5 item pernyataan dengan bantuan skala likert 4 poin memiliki rata-rata sebesar 16,38. Nilai rata-rata tersebut apabila dibagi dengan 5 item pernyataan diperoleh hasil sebesar 3,28. Nilai rata-rata variabel tingkat pendidikan sebesar 3,28 berada pada rentang 3,26 - 4,00 yang termasuk ke dalam kriteria sangat tinggi. Hal tersebut berarti bahwa tingkat pendidikan yang dimiliki oleh setiap karyawan yang ada di Koperasi Kabupaten Klungkung sudah sangat memadai dalam menunjang kinerjanya. Nilai standar deviasi tingkat pendidikan yaitu sebesar 2,637 yang nilainya lebih rendah dibandingkan dengan nilai rata-rata artinya sebaran data terkait dengan tingkat pendidikan sudah merata.

Variabel motivasi memiliki nilai minimum sebesar 8 dan nilai maksimum sebesar 20. Variabel motivasi diukur dengan 5 item pernyataan dengan bantuan skala likert 4 poin memiliki rata-rata sebesar 14,89. Nilai rata-rata tersebut apabila dibagi dengan 5 item pernyataan diperoleh hasil sebesar 2,98. Nilai rata-rata variabel motivasi sebesar 2,98 berada pada rentang 2,51 - 3,25 yang termasuk ke dalam kriteria tinggi. Hal tersebut berarti bahwa motivasi karyawan dalam melaksanakan tugas dan kewajibannya di Koperasi Kabupaten Klungkung tinggi. 
Nilai standar deviasi motivasi yaitu sebesar 2,888 yang nilainya lebih rendah dibandingkan dengan nilai rata-rata artinya sebaran data terkait dengan motivasi sudah merata.

Variabel kinerja memiliki nilai minimum sebesar 7 dan nilai maksimum sebesar 20. Variabel kinerja diukur dengan 5 item pernyataan dengan bantuan skala likert 4 poin memiliki rata-rata sebesar 13,24. Nilai rata-rata tersebut apabila dibagi dengan 5 item pernyataan diperoleh hasil sebesar 2,65. Nilai rata-rata variabel kinerja sebesar 2,65 berada pada rentang 2,51 - 3,25 yang termasuk ke dalam kriteria tinggi. Hal tersebut berarti bahwa kinerja karyawan dalam melaksanakan tanggung jawabnya di Koperasi Kabupaten Klungkung sudah tinggi. Nilai standar deviasi kinerja yaitu sebesar 3,528 yang nilainya lebih rendah dibandingkan dengan nilai rata-rata artinya sebaran data terkait dengan kinerja sudah merata.

Variabel gaya kepemimpinan situasional diukur dengan menggunakan 5 item pernyataan yang berhubungan dengan gaya kepemimpinan situasional dalam kinerja karyawan di Koperasi Kecamatan Klungkung. Rata - rata skor dari 5 item pernyataan mengenai gaya kepemimpinan situasional adalah sebesar 3,320. Nilai rata-rata tertinggi terdapat pada pernyataan 5 yaitu Pemimpin di tempat saya bekerja memberikan tanggung jawab kepada saya dalam melaksanakan pekerjaan, sebesar 3,489 dengan rincian 9 orang menjawab tidak setuju, 51 orang menjawab setuju, dan 75 orang menjawab sangat setuju. Hal tersebut berarti bahwa gaya kepemimpinan situasional yang diterapkan di Koperasi Kabupaten Klungkung sangat baik. Nilai rata-rata terendah terdapat pada pernyataan 4 yaitu Jika muncul permasalahan pemimpin ditempat saya bekerja bersedia membantu dan memberikan jalan keluar dan menjadikan suatu keputusan organisasi, sebesar 3,178 dengan rincian 18 orang menjawab tidak setuju, 75 orang menjawab setuju dan 42 orang menjawab sangat setuju. Hal tersebut menunjukkan bahwa di Koperasi Kecamatan Klungkung tidak sepenuhnya pemimpin bersedia membantu dan memberikan jalan keluar dan menjadikan suatu keputusan organisasi.

Variabel budaya organisasi diukur dengan 5 item pernyataan yang berhubungan dengan budaya organisasi dalam kinerja karyawan di Koperasi Kecamatan Klungkung. Rata - rata skor dari 5 item pernyataan mengenai budaya organisasi adalah sebesar 3,388. Nilai rata-rata tertinggi terdapat pada pernyataan 2 yaitu Jika timbul permasalahan di tempat kerja selalu diselesaikan bersamasama, sebesar 3,578 dengan rincian 3 orang menjawab tidak setuju, 51 orang menjawab setuju, dan 81 orang menjawab sangat setuju. Hal tersebut menunjukkan bahwa budaya organisasi memberikan dampak positif bagi kinerja karyawan di Koperasi Kecamatan Klungkung. Nilai rata-rata terendah terdapat pada pernyataan 5 yaitu Saya berusaha menjadi anggota satuan kerja yang kompak dan handal dalam menjalankan pekerjaan untuk mendapatkan hasil yang maksimal, sebesar 3,267 dengan rincian 12 orang menjawab tidak setuju, 75 orang menjawab setuju dan 48 orang menjawab sangat setuju. Hal tersebut menunjukkan bahwa dalam kinerja karyawan di Koperasi Kecamatan Klungkung para anggota masih belum kompak dan handal dalam menjalankan pekerjaan untuk mendapatkan hasil yang maksimal. 
Variabel tingkat pendidikan diukur dengan 5 item pernyataan yang berhubungan dengan tingkat pendidikan dalam kinerja karyawan di Koperasi Kecamatan Klungkung. Rata - rata skor dari 5 item pernyataan mengenai tingkat pendidikan adalah sebesar 3,275. Nilai rata-rata tertinggi terdapat pada pernyataan 5 yaitu Tempat saya bekerja, memberikan saya kesempatan mengikuti pendidikan dan pelatihan untuk mendukung kinerja, sebesar 3,467 dengan rincian 6 orang menjaw ab tidak setuju, 60 orang menjawab setuju, dan 69 orang menjawab sangat setuju. Hal tersebut menunjukkan bahwa tingkat pendidikan dan pelatihan karyawan mendukung kinerja karyawan di Koperasi Kecamatan Klungkung. Nilai rata-rata terendah terdapat pada pernyataan 3 yaitu Pendidikan formal membuat saya bisa melakukan pekerjaan dengan baik, dengan nilai rata-rata sebesar 3,133 terdiri dari 3 orang menjawab sangat tidak setuju, 15 orang menjawab tidak setuju, 78 orang menjawab setuju dan 39 orang menjawab sangat setuju. Hal tersebut menunjukkan bahwa pendidikan formal karyawan tidak sepenuhnya membuat karyawan melakukan pekerjaan dengan baik.

Variabel motivasi diukur dengan 5 item pernyataan yang berhubungan dengan motivasi dalam kinerja karyawan di Koperasi Kecamatan Klungkung. Rata -rata skor dari 5 item pernyataan mengenai motivasi adalah sebesar 2,977. Nilai rata-rata tertinggi terdapat pada pernyataan 5 yaitu Saya bertanggung jawab atas keluhan dan kenyamanan nasabah, sebesar 3,244 dengan rincian 6 orang menjawab sangat tidak setuju, 6 orang menjawab tidak setuju, 72 orang menjawab setuju, dan 51 orang menjawab sangat setuju. Hal tersebut menunjukkan bahwa motivasi dalam bekerja berdampak positif dalam kinerja karyawan di Koperasi Kecamatan Klungkung. Nilai rata-rata terendah terdapat pada pernyataan 4 yaitu Saya selalu melakukan inisiatif dan kreatif dalam melaksanakan tugas agar saya dapat mengerjakan suatu pekerjaan dengan cara yang lebih mudah, sebesar 2,800 dengan rincian 6 orang menjawab sangat tidak setuju, 36 orang menjawab tidak setuju, 72 orang menjawab setuju dan 21 orang menjawab sangat setuju. Hal tersebut menunjukkan bahwa karyawan tidak selalu mudah jika menyelesaikan pekerjaan dengan inisiatif dan kreatif.

Variabel kinerja diukur dengan 5 item pernyataan yang berhubungan dengan kinerja karyawan di Koperasi Kecamatan Klungkung. Rata - rata skor dari 5 item pernyataan mengenai kinerja adalah sebesar 2,608. Nilai rata-rata tertinggi terdapat pada pernyataan 2 yaitu Saya mampu menyelesaikan tugas yang diberikan secara teliti, sebesar 3,067 dengan rincian 21 orang menjawab tidak setuju, 84 orang menjawab setuju dan 30 orang menjawab sangat setuju. Hal tersebut menunjukkan bahwa karyaw an di Koperasi Kecamatan Klungkung dapat menyelesaikan pekerjaannya dengan teliti. Nilai rata-rata terendah terdapat pada pernyataan 4 yaitu Saya sangat disiplin dalam bekerja, sebesar 2,200 dengan rincian 39 orang menjawab sangat tidak setuju, 42 orang menjawab tidak setuju, 42 orang menjawab setuju dan 12 orang menjawab sangat setuju. Hal tersebut menunjukkan bahwa karyawan di Koperasi Kecamatan Klungkung masih belum sepenuhnya disiplin dalam melakukan pekerjaan. 
Tabel 4.Hasil Uji Normalitas

\begin{tabular}{lc}
\hline & Unstandardized Residual \\
\hline $\mathrm{N}$ & 135 \\
Kolmogorov-Smirnov Z & 0,068 \\
Asymp.Sig (2-tailed) & 0,200 \\
\hline
\end{tabular}

Sumber: Data Penelitian, 2020

Tabel 4 menunjukkan bahwa nilai Asymp. Sig (2-tailed) sebesar 0,200 lebih besar dari level of significant 5 persen yaitu $0,05(0,200>0,05)$, sehingga dapat disimpulkan bahwa variabel-variabel yang digunakan dalam penelitian ini berdistribusi normal.

Tabel 5. Hasil Uji Multikolinieritas

\begin{tabular}{lcc}
\hline \multicolumn{1}{c}{ Variabel } & Tolerance & VIF \\
\hline Gaya KepemimpinanSituasional & 0,747 & 1,339 \\
Budaya Organisasi & 0,819 & 1,221 \\
TingkatPendidikan & 0,856 & 1,168 \\
Motivasi & 0,781 & 1,280 \\
\hline
\end{tabular}

Sumber: Data Penelitian, 2020

Tabel 5 menunjukkan bahwa nilai tolerance dari masing - masing variabel bebas yang digunakan dalam penelitian ini bernilai lebih besar dari 10 persen $(0,10)$ dan VIF dari masing-masing variabel tersebut bernilai lebih kecil dari 10, sehingga dapat disimpulkan bahwa model persamaan regresi dalam penelitian ini bebas dari multikolinieritas.

Tabel 6. Hasil Uji Heteroskedastisitas

\begin{tabular}{lc}
\hline \multicolumn{1}{c}{ Variabel } & Sig. \\
\hline Gaya KepemimpinanSituasional & 0,895 \\
Budaya Organisasi & 0,066 \\
TingkatPendidikan & 0,120 \\
Motivasi & 0,124 \\
\hline
\end{tabular}

Sumber: Data Penelitian, 2020

Tabel 6 menunjukkan bahwa nilai signiifikansi dari masing-masing variabel bebas yang digunakan dalam penelitian ini nilainya lebih besar dari 0,05, sehingga dapat disimpulkan bahwa model persamaan regresi yang digunakan dalam penelitian ini tidak mengandung gejala heteroskedastisitas.

Tabel 7. Hasil Uji Koefisien Determinasi $\left(\mathbf{R}^{2}\right)$

\begin{tabular}{ccccc}
\hline Model & $\mathrm{R}$ & R Square & Adjusted R Square & Std. Error of the Estimate \\
\hline 1 & 0,692 & 0,479 & 0,463 & 2,192 \\
\hline
\end{tabular}

Sumber: Data Penelitian, 2020

Berdasarkan Tabel 7 dilihat nilai dari adjusted $R$ Square adalah sebesar 0,463 atau 46,3 persen yang memiliki arti bahwa 46,3 persen variansi kinerja karyawan dipengaruhi oleh variansi gaya kepemimpinan situasional, budaya organisasi, tingkat pendidikan, dan motivasi, sisanya sebesar 53,7 persen dipengaruhi oleh variabel-variabel lain yang tidak dijelaskan dalam penelitian ini.

Tabel 8. Hasil Uji Kelayakan Model (Uji F)

\begin{tabular}{lccccc}
\hline \multicolumn{1}{c}{ Model } & Sum of Squares & df & Mean Square & F & Sig. \\
\hline 1 Regression & 574,696 & 4 & 143,674 & 29,914 & 0,000 \\
Residual & 624,385 & 130 & 4,803 & & \\
Total & 1199,081 & 134 & & & \\
\hline
\end{tabular}

Sumber: Data Penelitian, 2020 
Tabel 8, menunjukkan bahwa nilai signifikansi sebesar 0,000 lebih kecil dari 0,05. Hal ini berarti bahwa secara simultan gaya kepemimpinan situasional, budaya organisasi, tingkat pendidikan, dan motivasi berpengaruh terhadap kinerja karyawan di Koperasi Kabupaten Klungkung.

Tabel 9. Hasil Analisis Regresi Linear Berganda

\begin{tabular}{lcccc}
\hline \multicolumn{1}{c}{ Variabel } & Unstandardized Beta & Std. Error & thitung & Sig. \\
\hline (Constant) & 1,536 & 1,451 & 1,058 & 0,292 \\
Gaya Kepemimpinan & 0,242 & 0,067 & 3,613 & 0,000 \\
$\begin{array}{l}\text { Situasional } \\
\text { Budaya Organisasi }\end{array}$ & 0,150 & 0,071 & 2,117 & 0,036 \\
Tingkat Pendidikan & 0,229 & 0,057 & 3,989 & 0,000 \\
Motivasi & 0,321 & 0,073 & 4,395 & 0,000 \\
\hline
\end{tabular}

Sumber: Data diolah, 2020

Berdasarkan Tabel 9, Nilai konstanta (a) sebesar 1,536 memiliki arti bahwa apabila variabel gaya kepemimpinan situasional, budaya organisasi, tingkat pendidikan, dan motivasi bernilai 0 (nol), maka nilai kinerja karyawan adalah sebesar 1,536. Nilai koefisien regresi gaya kepemimpinan situasional $\left(X_{1}\right)$ sebesar 0,242 memiliki arti bahwa gaya kepemimpinan situasional memiliki hubungan positif terhadap kinerja karyawan. Nilai koefisien regresi budaya organisasi $\left(X_{2}\right)$ sebesar 0,150 memiliki arti bahwa budaya organisasi memiliki hubungan positif terhadap kinerja karyawan, Nilai koefisien regresi tingkat pendidikan $\left(X_{3}\right)$ sebesar 0,229 memiliki arti bahwa tingkat pendidikan memiliki hubungan positif terhadap kinerja karyawan. Nilai koefisien regresi motivasi $\left(X_{4}\right)$ sebesar 0,321 memiliki arti bahwa motivasi memiliki hubungan positif terhadap kinerja karyawan.

Hasil pengujian menunjukkan, nilai koefisien regresi variabel gaya kepemimpinan situasional bernilai positif yaitu sebesar 0,242 dengan nilai signifikansi sebesar 0,000. Nilai signifikansi sebesar 0,000 $<0,05$ sehingga $\mathrm{H}_{1}$ diterima. Hal ini berarti bahwa gaya kepemimpinan situasional berpengaruh positif terhadap kinerja karyawan. Berdasarkan Teori Atribusi yang menjelaskan bahwa situasi di sekitar yang menyebabkan perilaku seseorang dalam persepsi sosial yang disebut dengan dispositional attributions dan situasional attributions. Gaya kepemimpinan situasional berhubungan dengan situasional attributions yang artinya penyebab eksternal yang mengacu pada lingkungan sekitar yang dapat memengaruhi perilaku seseorang. Hal ini berarti bahwa, ketika suatu organisasi menerapkan kepemimpinan situasional dengan tepat dan semakin baik sesuai dengan situasi dan lingkungan kerja organisasi, maka akan mampu memengaruhi secara positif perilaku karyawan salah satunya adalah dengan meningkatnya kinerja karyawan. Hasil penelitian ini sejalan dengan penelitian yang dilakukan oleh Rahadiyan et al. (2019), Samsuri et al. (2020), Setyorini et al. (2018) yang menyatakan bahwa gaya kepemimpinan situasional berpengaruh positif terhadap kinerja karyawan.

Hasil pengujian menunjukkan bahwa nilai koefisien regresi variabel budaya organisasi bernilai positif yaitu sebesar 0,150 dengan nilai signifikansi sebesar 0,036 . Nilai signifikansi sebesar $0,036<0,05$ sehingga $\mathrm{H}_{2}$ diterima. Hal ini berarti bahwa budaya organisasi berpengaruh positif terhadap kinerja karyawan. Teori keperilakuan organisasi menyatakan bahwa organisasi yang menyangkut aspek pengaruh organisasi terhadap manusia berhubungan dalam budaya 
organisasi. Hal tersebut dikarenakan seorang anggota organisasi akan cenderung mempersepsikan budaya organisasi berdasarkan apa yang mereka lihat atau dengar di dalam organisasi, sehingga akan memberi pengaruh terhadap kinerja karyaan dalam suatu organisasi. Hasil penelitian ini sejalan dengan penelitian yang dilakukan oleh Wardani et al. (2016), Perawati dan Badera (2018), Isa et al. (2016), Hardiyono et al. (2017), Paschal \& Nizam (2016).

Hasil pengujian menunjukkan bahwa nilai koefisien regresi variabel tingkat pendidikan bernilai positif yaitu sebesar 0,229 dengan nilai signifikansi sebesar 0,000 . Nilai signifikansi sebesar $0,000<0,05$ sehingga $\mathrm{H}_{3}$ diterima. Hal ini berarti bahwa tingkat pendidikan berpengaruh positif terhadap kinerja karyawan. Dengan berbekal tingkat pendidikan yang dimiliki, seseorang individu akan mampu menghadapi persoalan-persoalan yang dihadapi ketika berkaitan dengan profesinya. Dalam suatu organisasi, selain pengalaman yang dimiliki oleh seorang karyawan, ilmu pengetahuan yang diperoleh dalam pendidikan yang ditempuh juga mampu menunjang kinerja karyawan tersebut. Ketika seseorang memiliki tingkat pendidikan yang semakin tinggi, maka pengetahuan yang dimiliki semakin luas sehingga pekerjaan yang dilakukan dapat terselesaikan dengan lebih baik. Salwa et al. (2019), Abdulrahamon et al. (2018) menemukan bahwa tingkat pendidikan berpengaruh positif terhadap kinerja karyawan.

Hasil pengujian menunjukkan bahwa nilai koefisien regresi variabel motivasi bernilai positif yaitu sebesar 0,321 dengan nilai signifikansi sebesar 0,000. Nilai signifikansi sebesar $0,000<0,05$ sehing $\mathrm{H}_{4}$ diterima. Hal ini berarti bahwa motivasi berpengaruh positif terhadap kinerja karyawan. Motivasi diartikan sebagai suatu kekuatan yang mendorong seseorang untuk melakukan sesuatu agar memperoleh hasil atau tujuan yang diharapkan. Dalam lingkup organisasi, motivasi kerja merupakan tekanan psikologis dalam diri seorang yang menentukan arah perilakunya dalam organisasi, tingkat usaha, maupun tingkat ketahanannya dalam menghadapi hambatan- hambatan. Karyawan akan termotivasi untuk memberikan hasil kerja yang baik apabila dia memperoleh imbalan yang memadai atas pekerjaan yang telah dilakukan baik berupa bonus, penghargaan, ekstra cuti dan sebagainya. Hasil penelitian ini sejalan dengan penelitian yang dilakukan oleh Robescu \& Iancu (2016), Kuranchie-Mensah \& Amponsah-Tawiah (2016), Noviani dan Widhiyani (2018), Hikmah dan Sherlie (2020).

\section{SIMPULAN}

Berdasarkan hasil penelitian maka dapat disimpulkan, gaya kepemimpinan situasional berpengaruh positif terhadap kinerja karyawan di Koperasi Kabupaten Klungkung; budaya organisasi berpengaruh positif terhadap kinerja karyawan di Koperasi Kabupaten Klungkung; Tingkat pendidikan berpengaruh positif terhadap kinerja karyawan di Koperasi Kabupaten Klungkung dan Motivasi berpengaruh positif terhadap kinerja karyawan di Koperasi Kabupaten Klungkung.

Koperasi disarankan untuk memembantu dan memberikan jalan keluar dan menjadikan suatu keputusan organisasi untuk membantu menyelesaikan permasalahan yang terjadi; mengadakan suatu program pelatihan yang berguna untuk melatih anggota satuan kerja yang kompak dan handal dalam menjalankan 
pekerjaan serta menjelaskan tugas kerja dan tanggung jawab karyawan sesuai dengan job description sehingga nantinya karyawan dapat mengetahui dan memahami apa saja yang menjadi tanggung jawabnya dan akan meningkatkan kinerjanya menjadi lebih optimal bagi koperasi; merekrut pegawai yang memiliki pendidikan formal dapat tetap memperhatikan pengalaman yang dimiliki pegawai tersebut, sehingga pegawai tersebut dapat melakukan pekerjaan dengan baik; memberikan reward pada karyawannya yang kreatif, sehingga karyawan akan menjadi lebih termotivasi untuk melakukan inisiatif dan kreatif dalam melaksanakan tugasnya; meningkatkan disiplinnya sehingga dapat bekerja secara optimal serta memberikan sanksi tegas seperti memberikan denda bagi karyawan yang tidak disiplin, sehingga karyawan akan menjadi lebih disiplin.

Bagi Peneliti selanjutnya disarankan untuk memperluas wilayah penelitian di kabupaten dan provinsi lainnya sehingga hasil penelitian dapat lebih digeneralisasikan dan menambahkan variabel lain khususnya faktor-faktor yang dapat memengaruhi kinerja karyawan, seperti lingkungan kerja, komunikasi, dan pengembangan diri karyaw an yang tidak diteliti dalam penelitian ini.

\section{REFERENSI}

Abdulrahamon, A., Toyin Adeleye, S., \& Adeola, F. (2018). Impact of Educational, Professional Qualification and Years of Experience on Accountant Job Performance. Journal of Accounting and Financial Management, 4(1), 32-44. https:/ / doi.org/10.5281/zenodo.1210796

Anjani, P. W., \& Wirawati, N. G. P. (2018). Pengaruh Usia, Pengalaman Kerja, Tingkat Pendidikan, dan Kompleksitas Tugas terhadap Efektivitas Pengguna Sistem Informasi Akuntansi. E-Jumal Akuntansi, 22(3), 2430-2457. https:/ / doi.org/10.24843/EJA.2018.v22.i03.p29

Aprila, Z. A., \& ArthaWibawa, I. M. (2020). The Effect Of Organizational Culture, Work Motivation And Work Experience On Employee Performance. American Journal of Humanities and Social Sciences Research (AJHSSR), 4(8), 6873.

Azizah, F. N., Thoyib, A., \& Irawanto, D. W. (2017). Pengaruh Kepemimpinan Situasional Dan Budaya Organisasi Terhadap Motivasi Kerja Dan Kinerja Karyawan (Studi Pada Koperasi Agro Niaga (KAN) Jabung Malang). Jurnal Bisnis Dan Manajemen, 4(1), 1-11.

Belawa, P. D., \& Pande Dwiana Putra, I. M. (2018). Pengaruh Intensif, Tingkat Pendidikan, Pelatihan Dan Pengalaman Kerja Pada Kinerja Individu Pengguna Sistem Informasi Akuntansi. E-Jurnal Akuntansi, 22, 653. https:/ / doi.org/10.24843/eja.2018.v22.i01.p25

Dermawan, P., Susilo, H., \& Aini, E. K. (2018). Pengaruh Gaya Kepemimpinan Situasional Terhadap Kinerja Karyawan Dengan Motivasi Kerja Sebagai Variabel Intervening (Studi Pada PT Anugerah Sinergi Raya .... Jurnal Administrasi Bisnis, 60(2), 95-104.

Fajrin, I. Q., \& Susilo, H. (2018). Pengaruh Gaya Kepemimpinan Terhadap Kinerja Karyawan dengan Motivasi Kerja sebagai Variabel Intervening (Studi pada Karyawan Pabrik Gula Kebon Agung Malang). Jurnal Administrasi Bisnis, 1(1), 1.

Hardiyono, H., Hamid, N., \& Yusuf, R. (2017). The Effect Of Work Environment 
And Organizational Culture On Employees' Performance Through Job Satisfaction As Intervening Variable At State Electriciy Company (Pln) Of South Makassar Area. Advances in Economics, Business and Management Research, 40(Icame), 86-96. https:// doi.org/10.2991/icame-17.2017.7

Hidayat, N.,Hamid, D., \& Ika, R. (2014). Pengaruh gaya kepemimpinan situasional dan budaya organisasi terhadap kepuasan kerja. Administrasi Bisnis, 26(1), 19.

Hikmah, \& Sherlie. (2020). Pengaruh Motivasi, Disiplin Kerja dan Kompensansi Terhadap Kinerja Karyawan Pada PT Benwin Indonesia di Kota Batam. MOTIVASI Jurnal Manajemen Dan Bisnis, 5(1), 755-765.

Isa, M. F. M., Ugheoke, S. O., \& Noor, W. S. W. M. (2016). The Influence of Organizational Culture on Employees' Performance: Evidence from Oman. Journal of Entrepreneurship and Business, 4(2), 1-12. https:/ / doi.org/10.17687/jeb.0402.01

Karma, K., Yasa, G., \& Ratnadi, N. M. (2017). Pengaruh Gaya Kepemimpinan Situasional, Budaya Organisasi Dan Motivasi Pada Kinerja Karyawan. EJurnal Akuntansi Universitas Udayana, 1(1), 1.

Kodyawati, P., \& Dewi, L. G. K. (2019). Pengaruh Independensi Keahlian Profesi Motivasi Kerja Pengalaman Kerja Dan Tingkat Pendidikan Terhadap Kinerja Pengawas Koperasi. E-Jurnal Akuntansi, 27(1), 1597. https:/ / doi.org/10.24843/eja.2019.v27.i02.p29

Kuranchie-Mensah, E. B., \& Amponsah-Tawiah, K. (2016). Employee motivation and work performance: A comparative study of mining companies in Ghana. Journal of Industrial Engineering and Management (JIEM), 9(2), 255-309. https:/ / doi.org/http://dx.doi.org/10.3926/jiem.1530

Noviani, N. L. K. S., \& Widhiyani, N. L. S. (2018). Pengaruh Gaya Kepemimpinan Situasional, Motivasi dan Pelatihan pada Kinerja Karyawan di Koperasi Pasar Srinadi Klungkung. E-Jurnal Akuntansi, 1(1), 1. https:/ / doi.org/10.24843/eja.2018.v25.i03.p22

Paschal, A. O., \& Nizam, D. I. (2016). Effects of Organisational Culture on Employees Performance: International Journal of Accounting and Business Management, $4(1)$, 19-26. https:/ / doi.org/10.24924/ijabm/2016.04/v4.iss1/19.26

Perawati, K. M., \& Badera, I. D. N. (2018). Pengaruh Gaya Kepemimpinan Transformasional, Budaya Organisasi dan Komitmen Organisasi pada Kinerja Organisasi. E-Jurnal Akuntansi, 25(1), 1856. https:/ / doi.org/10.24843/eja.2018.v25.i03.p09

Putra, I. N. A., \& Setiawan, P. E. (2020). The Effect of Taxpayer Awareness, Service Quality, Taxation Understanding, and Application of E-Filling System on Corporate Taxpayer Compliance. American Journal of Humanities and Social Sciences Research (AJHSSR), 4(2), 219-224.

Rahadiyan, A., Triatmanto, B., \& Respati, H. (2019). The Effect of Motivation and Situational Leadership Style Towards Employee Performance Through Work Satisfaction at Developer Company. International Journal of Advances in Scientific Research and Engineering, 5(4), 249-256. https:/ / doi.org/10.31695/ijasre.2019.33162

Robescu, O., \& Iancu, A.-G. (2016). The Effects of Motivation on Employees 
Performance in Organizations. Valahian Journal of Economic Studies, 7(2), 4956. https:/ / doi.org/10.1515/vjes-2016-0006

Rudiantoro, Y. (2017). Pengaruh Motivasi Dan Budaya Organisasi Terhadap Kinerja Karyawan. Jurnal Sosial Humaniora., 2(2), 1-10. https:/ / doi.org/10.30997/jsh.v8i1.701

Sahyoni, N. K. T., \& Supartha, I. W. G. (2020). The effect of organizational culture,organizational commitments and job satisfaction on organizational citizenship behaviour. American Journal of Humanities and Social Sciences Research, 4(3), 425-432.

Salwa, Kristiawan, M., \& Lian, B. (2019). The effect of academic qualification, work experience and work motivation towards primary school principal performance. International Journal of Scientific and Technology Research, 8(8), 969-980. https:/ / doi.org/10.31219/osf.io/ u4kzt

Samsuri, Rianse, U., Husin, \& Patyawati. (2020). Effects of situational leadership style on organizational culture, spirituality and employee performance. International Journal of Scientific and Technology Research, 9(3), 1273-1277.

Sawitri, M., Dewi, K., Wirakusuma, M. G., Rasmini, N. K., \& Ramantha, I. W. (2020). The Effect of Professional Skepticism , Locus of Control , and Integrity on Audit Judgment. American Journal of Humanities and Social Sciences, 4(1), 157-164.

Setyorini, R. W., Yuesti, A., \& Landra, N. (2018). The Effect of Situational Leadership Style and Compensation to Employee Performance with Job Satisfaction as Intervening Variable at PT Bank Rakyat Indonesia (Persero), Tbk Denpasar Branch. International Journal of Contemporary Research and Review, 9(08), 20974-20985. https:// doi.org/10.15520/ijcrr/2018/9/08/570

Wang, H. J., Du, S. H., Yue, X., \& Chen, C. X. (2020). Review and Prospect of Pathological Features of Corona Virus Disease. Journal of Forensic Medicine, 1(1), 1. https:// doi.org/10.12116/j.issn.1004-5619.2020.01.004

Wardani, R. K., Mukzam, D. M., \& Mayow an, Y. (2016). (Studi Pada Karyawan PT Karya Indah Buana Surabaya ). Jurnal Administrasi Bisnis (JAB), 31(1), 58-65.

Wiradana, M. R., \& Dewi, G. A. M. (2021). Organization Culture and Employee Attitude and Behavior: A Test of Social Exchange Theory. American Journal of Humanities and Social Sciences Research, 1(3), 218-231. 